Wojciech Kowalewski

Ewangelikalna Wyższa Szkoła Teologiczna we Wrocławiu

\title{
Protestantyzm a islam w ujęciu misjologicznym
}

Obecność misjonarzy chrześcijańskich wśród muzułmanów od początków ruchu misyjnego wzbudzała wiele kontrowersji. Historia misji wyraźnie wskazuje na niechlubne przykłady utożsamiania idei misyjnej z kolonializmem i triumfalistycznym podejściem do niechrześcijańskich kultur i społeczeństw. Wiele stowarzyszeń misyjnych zbyt łatwo przekładało swoje samolubne ambicje imperialne na praktykę misji ${ }^{1}$.

Tego rodzaju podejście do misji często prowadziło do przedmiotowego traktowania innych kultur i religii jako terenów do zdobycia i w efekcie do narastających konfliktów oraz podziałów. Miało to również wielki wpływ na kształtowanie się określonego obrazu relacji między misjonarzami chrześcijańskimi a muzułmanami.

Odnosząc się do tematu „Protestantyzm a islam w ujęciu misjologicznym”, najpierw krótko nakreślę istotne zmiany w globalnych trendach misyjnych w XX wieku, następnie to, jak w ujęciu protestanckim wyglądają współczesne założenia dotyczące chrześcijańskiej obecności i misji wśród muzułmanów, a całość zakończę podsumowaniem Praskiej Deklaracji dotyczącej relacji pomiędzy chrześcijaństwem a islamem.

\section{Zmiany w globalnych trendach misjologicznych}

Dwudziesty wiek był czasem wielu zmian i transformacji w myśleniu i praktyce misji. Po entuzjazmie wzbudzonym okresem nacechowanym wielkim aktywizmem misyjnym w XIX wieku, od 1900 do 1950 roku odbyło się wiele światowych konferencji misyjnych, na których stopniowo zaczęto formułować zagadnienia

\footnotetext{
${ }^{1}$ Genezę takiego pojmowania misji trafnie krytykuje brytyjski misjolog Timothy Yates, określając to zjawisko „duchowym imperializmem”, który objawiał się mniej lub bardziej intensywnie w różnych okresach historii chrześcijaństwa - zob. T. Yates, Christian Mission in the Twentieth Century, Cambridge 1994.
} 
związane z różnymi religiami. Początek XX wieku był jednak w dużym stopniu kontynuacją ruchu misyjnego ukierunkowanego na ekspansję chrześcijaństwa na całym świecie. Wielki wpływ na rozwój idei i praktyki misji protestanckiej w XIX wieku miał William Carey (1761-1834), który jest nazywany „ojcem współczesnej misji"’2. Podkreślał on wagę głoszenia Ewangelii w każdy możliwy sposób, tłumaczenie i propagowanie Biblii oraz kształcenie teologiczne duchowieństwa w językach narodowych tych kultur i społeczności, w których podejmowana była praca misyjna. Innym trendem mocno promowanym przez protestancki ruch misyjny była wizja tworzenia miejscowych kościołów. Jednym z najbardziej wybitnych propagatorów koncepcji zakładania kościołów, które powinny stać się „niezależne finansowo”, „samorządne” i ,prowadzące własną działalność misyjną" był Henry Venn (1796-1873), sekretarz angielskiego stowarzyszenia misyjnego - Church Missionary Society ${ }^{3}$. Założenia misjologii Venna były znaczącym osiągnięciem w uwzględnieniu roli lokalnych kultur i próbą zerwania z etnocentryzmem skupiającym się na propagowaniu wyższości chrześcijaństwa zachodniego nad wszelkimi innymi formami religijności. Niestety poglądy te odrzuciły inne anglikańskie stowarzyszenia misyjne, decydując się na stałą kontrolę kościołów z ośrodków w Europie. Stąd język podboju, zdobywania świata i ekspansji był nadal mocno eksploatowany w pierwszej połowie XX wieku.

Światowa Konferencja Misyjna w Edynburgu w 1910 roku w tradycyjnym stylu nawoływała do pozyskiwania niewierzących w Azji, Afryce i Ameryce Południowej, przyjmując za oczywiste, iż niezaprzeczalnym, głównym i naglącym zadaniem Kościoła jest wypełnianie wielkiego posłannictwa Chrystusa ${ }^{4}$. Zasadniczym pytaniem w tym czasie nie było badanie podstaw teologicznych misji, ale raczej szukanie strategii, aby jak najlepiej i najefektywniej doprowadzić do ekspansji chrześcijaństwa w różnych kulturach. Przekonanie o potrzebie ewangelizacji całego świata było jednym z głównych motywów misjonarzy, by udać się do różnych plemion i wiosek na krańcach ziemi i poświęcić życie głoszeniu dobrej nowiny o zbawieniu w Jezusie Chrystusie. Entuzjazm i optymizm związany z tym okresem został jasno wyrażony w wizji Ochotniczego Ruchu Studenckiego (Student Volunteer Movement): „Ewangelizacja świata

${ }^{2}$ J. Reapsome, Carey, William, [w:] Evangelical Dictionary of World Missions, general editor A. S. Moreau, Grand Rapids 2000, s. 162.

${ }^{3}$ Henry Venn napisał w jednym ze swoich traktatów: ,Jeśli podstawowe zasady samofinansowania się, samorządności i własnej działalności misyjnej będą zasiane wraz z ziarnem ewangelii, możemy mieć nadzieję na zdrowy rozwój i rozrost miejscowego kościoła, kiedy Duch będzie wylany z góry, tak samo jak kwiaty na żyznym polu mnożą się w deszczu i cieple lata" (cyt. za: N. E. Thomas, Classic Texts in Mission and World Christianity, Maryknoll 1995, s. 207).

${ }^{4}$ G. H. Anderson, Christian Mission in A. D. 2000. A Glance Backward, ,Missiology. An International Review" 28 (2000) nr 3, s. 276. 
w tym pokoleniu"5. Według Motta oznaczało to, że zbawienie dokonane przez Chrystusa ,powinno być znane wszystkim, aby wszyscy mogli w Niego uwierzyć i zostać zbawieni." ${ }^{\circ} \mathrm{W}$ konsekwencji dzieło dalszej edukacji konwertytów było dla wielu misjonarzy drugoplanowe i nie stanowiło podstawy ich zaangażowania. W uproszczeniu można więc podsumować, że świat w ujęciu stowarzyszeń misyjnych na początku XX wieku był dualistycznie podzielony na dwa geograficzne regiony: 'chrześcijański' i 'niechrześcijański,' który wymaga intensywnej ewangelizacji ${ }^{7}$. W związku z takim postrzeganiem misji, wszelkie zagadnienia związane z innymi religiami cechowało poczucie braku ciągłości między objawieniem chrześcijańskim a różnymi religiami.

Początek kształtowania się nowego paradygmatu w refleksji misyjnej można datować od zjazdu Światowej Rady Misyjnej w Wilingen w 1952 roku. Właśnie tam missio Dei zostało uznane za podstawową zasadę rozumienia misji chrześcijańskiej ${ }^{8}$. Poprzez połączenie doktryny Trójcy Świętej z powołaniem misyjnym Kościoła w świecie, konferencja w Wilingen rozpoczęła nowy etap we współczesnej refleksji misyjnej znacznie wykraczającej poza tradycyjne eklezjocentryczne missiones ecclesiae. Mianowicie, idea missio Dei, bez zaprzeczenia ważności zaangażowania ludzkiego, podkreśla, iż zasadność i dynamikę misji określa sam Bóg.

Wcześniej niejako Kościół posyłał i delegował misję, natomiast w świetle misjologii opartej na missio Dei to Kościół jest posłany, a przez to sam staje się obiektem misji. Zatem misja rozumiana z perspektywy missio Dei jest wyzwaniem dla czysto pragmatycznych modeli misji nastawionych jedynie na duchowy aktywizm, planowanie i ciągłe poszukiwanie nowych strategii będących wynikiem ludzkiego działania bez wystarczającego nacisku na dynamikę odkrywania i realizowania Bożej misji ${ }^{9}$. Wobec tak sformułowanego

${ }^{5}$ P. G. Hiebert, Evangelism, Church, and Kingdom, [w:] The Good News of the Kingdom. Mission Theology for the Third Millennium, ed. by C. Van Engen, D. S. Gilliland, P. Pierson, Maryknoll 1993, s. 153.

${ }^{6}$ J. Scherer, Gospel, Church and Kingdom. Comparative Studies in World Mission Theology, Minneapolis 1987, s. 15.

${ }^{7}$ Ten podział wyraźnie widać z raportu spotkania Międzynarodowej Rady Misyjnej (International Mission Council) w Jerozolimie w 1928 roku. Dopiero podczas spotkania w Tambaram-Madrasie w 1938 roku, gdzie po raz pierwszy liczba delegatów z Afryki, Azji i Ameryki Południowej była znacznie większa, dokonano zmian w tej nomenklaturze. Zostało to wyrażone w zniesieniu formalnego podziału pomiędzy tzw. „starszymi” a „młodszymi” kościołami w krajach misyjnych.

${ }^{8}$ Termin missio Dei został już wcześniej użyty w odniesieniu do misji przez Karola Bartha podczas misyjnej konferencji w Brandenburgu w 1932 roku, a także później przez Karla Harltensteina, ale dopiero konferencja w Wilingen spopularyzowała go na szerszą skalę - zob. J. Aagaard, Trends in Missiological Thinking During the Sixties, „International Review of Mission" 62 (1973) nr 245, s. 8-25.

${ }^{9}$ Zob. P. Penner, Discerning and Following God's Mission, „Journal of European Baptist Studies" 4 (2004) nr 2, s. 34-39. 
wyznania misyjnego oparcie nauki dotyczącej misyjności Kościoła na teologii misji Osób Boskich ma poważne implikacje. Takie trynitarne, a nie jak dotychczas chrystocentryczne rozumienie misji dało początek nowym trendom misyjnym. Podstawowym założeniem wypływającym z idei missio Dei jest to, że misja czerpie swą inspirację i kierunek, wzorując się na tym, kim jest Bóg, a w szczególności na Bożej ofiarnej miłości wobec stworzenia. Jeśli ta miłość jest rozumiana w wymiarze społecznym i przekłada się na więzi, oznacza to, że misja chrześcijańska powinna być odzwierciedleniem Bożych celów dla stworzenia: miłości, wspólnoty, równości, różnorodności, miłosierdzia, współczucia i sprawiedliwości ${ }^{10}$. Szczególnego znaczenia w tym kontekście nabrała więc problematyka 'innego' a z misjologicznego punktu widzenia relacji pomiędzy chrześcijaństwem a innymi religiami. W szerszej perspektywie, nie chodziło tu bynajmniej o zatarcie różnic czy też zatracenie swojej odrębnej tożsamości, ale raczej odkrycie na nowo szerokiej przestrzeni inspirowanej przez chrześcijaństwo i misje w różnych kulturach. W tym ujęciu teologia otwarta i podchodząca z szacunkiem do 'innego' prowadzi do uznania istnienia kogoś innego za błogosławieństwo dla nas samych. W misjologii w drugiej połowie XX wieku, szczególnie w kręgach reprezentowanych przez Światową Radę Kościołów, powołaną do życia w 1948 roku, widać wyraźnie rozwój w tym kierunku, co jest też z pewnością w dużej mierze zasługą coraz bardziej słyszalnego głosu chrześcijan z Ameryki Południowej, Azji i Afryki.

W tym miejscu warto nawiązać do teologii Davida J. Boscha, uważanego za jednego z najwybitniejszych misjologów XX wieku, który jako pierwszy odniósł teorię paradygmatów Thomasa Kuhna do teologii misji ${ }^{11}$. Po dogłębnym studium historii misji na przełomie wieków, poczynając od nowotestamentowych podstaw, poprzez okresy Średniowiecza, Reformacji i Oświecenia, Bosch określa obecnie zachodzące zmiany misjologiczne w kontekście wyłaniającego się postmodernistycznego paradygmatu, który nazywa 'ekumenicznym' ${ }^{12}$. Studium zmieniających się paradygmatów misji opisanych przez Davida Boscha wskazujące na różnorodność rozumienia jak i praktyki misji zakłada konieczność uwzględnienia wielości istniejących stanowisk, które mogą mieć twórczy wpływ na siebie nawzajem i w efekcie pomóc w realizacji chrześcijańskiego posłannictwa misyjnego. Nie oznacza to relatywizacji prawdy czy też rezygnacji ze słuszności wyznawanych przez siebie podstaw wiary, ale wymaga docenienia otwartości na inność. W takim duchu dowartościowanie różnorodności działań

${ }^{10}$ Andrew J. Kirk, What is Mission? Theological Explorations, London 1999, s. 28.

${ }^{11}$ D. Bosch, Transforming Mission. Paradigm Shifts in Theology of Mission, Maryknoll 1991.

${ }^{12}$ Paradygmat ten zawiera m.in. takie elementy składowe jak misyjność Kościoła, missio Dei, ewangelizacja, kontekstualizacja, teologia wyzwolenia, inkulturacja, dialog, misyjna rola teologii, odnowiona refleksja eschatologiczna - zob. tamże, s. 368-521. 
misyjnych w styczności z innymi religiami stało się jednym z głównych zadań Kościoła zaangażowanego w misje.

Zmiany, które zaszły w drugiej połowie $\mathrm{XX}$ wieku, można więc określić w kategoriach przechodzenia od eklezjocentrycznego modelu misji ku nowemu paradygmatowi w oparciu o holistyczne podejście. W dużej mierze stanowisko to zakłada, że posłannictwo chrześcijańskie nie jest ograniczone jedynie do duchowego wpływania na rzeczywistość, ale dotyczy każdej sfery życia w oparciu o dobrą nowinę królestwa Bożego. W świetle tego rozumienia słowna proklamacja ewangelii nie może być oddzielona od działalności społecznej. Te dwa aspekty stanowią nierozerwalną całość i jedno bez drugiego nie odzwierciedla pełni Chrystusowego posłannictwa. Holistyczne podejście do rzeczywistości w odniesieniu do misji połączone $\mathrm{z}$ dynamicznie kształtującą się globalnie teologią religii zaczęło również kłaść większy nacisk na dialog jako integralną część misji. W związku z tymi zmianami misjolodzy zaczęli coraz bardziej skupiać się na poszukiwaniu adekwatnych kulturowo form misji dostosowanych do lokalnych warunków. Ten proces znacznie zdynamizował rozumienie relacji pomiędzy lokalnym kontekstem kulturowym, teologią a misją. Stąd wypływa też szerokie zainteresowanie metodą kontekstualizacji w praktyce misji, które trwa do dzisiaj i ma duże znaczenie w protestantanckiej misjologii. Istnieje wiele różnych definicji i podejść do procesu kontekstualizacji ${ }^{13}$. Większość misjologów zgadza się co do tego, że kontekst lokalny ma duży wpływ na to, jak się kształtują wyznawane prawdy wiary, priorytety i działania w danej kulturze. To oznacza, że prawidłowo wypełniana misja powinna być poprzedzona zrozumieniem kontekstu lokalnej kultury. Amerykański misjolog Darrell Whiteman definiuje więc kontekstualizację jako proces „,komunikowania Ewangelii w słowie i działaniu, umożliwiający powoływanie do życia kościołów, które będą osadzone w realiach lokalnego kontekstu kulturowego, prezentując chrześcijaństwo w sposób jednocześnie zaspokajający najgłębsze potrzeby ludzi i przenikający ich światopogląd, umożliwiając naśladowanie Chrystusa i pozostanie w ich własnej kulturze."14 Należy więc zastanowić się, w jaki sposób taki model działań misyjnych jest realizowany w pracy misyjnej wśród muzułmanów.

${ }^{13} \mathrm{~S}$. Bevans wyróżnia przynajmniej pięć modeli kontektualizacji kładących nacisk na różne aspekty relacji pomiędzy kontekstem, teologią a misją: model thumaczenia, model antropologiczny, model syntetyczny, model praxis i model transcendentny. Każdy z tych modeli ma swoje ograniczenia i żaden nie jest wyczerpujący - zob. S. Bevens, Models of Contextual Theology, Maryknoll 2000; por. D. J. Hesselgrave, E. Rommen, Contextualization. Meanings, Methods and Models, Grand Rapids 1992.

${ }^{14}$ D. L. Whiteman, Contextualization. The Theory, the Gap, the Challenge, „International Bulletin of Missionary Research" 1 (1997), s. 2. 


\section{Budowanie pomostów między chrześcijaństwem a islamem}

Aby móc budować dialogiczne pomosty pomiędzy chrześcijaństwem a islamem, w świetle nowego ekumenicznego paradygmatu misji należy wpierw uświadomić sobie i skorygować niewłaściwe postawy i założenia misjonarzy chrześcijańskich. Wcześniejsze założenia były takie, że misjonarze wkraczali do muzułmańskiej kultury z wizją chrystianizacji w stylu zachodnim, bez zachowania właściwego szacunku dla wartości religijnych głęboko osadzonych w danej kulturze. Taka postawa sprzyjała rozwojowi wzajemnych uprzedzeń, a nawet konfliktów. Mentalność krucjaty reprezentowana przez wielu chrześcijańskich misjonarzy nastawionych na zdobywanie nowych konwertytów wśród muzułmanów często owocowała antagonistycznym nastawieniem wyznawców islamu wobec chrześcijan.

Należy jednak zauważyć, że z perspektywy prawd zawartych w Piśmie

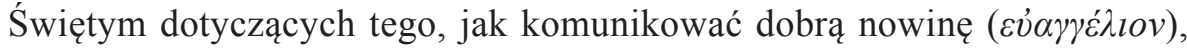
wyznawcy Chrystusa są pouczani, by robić to z „łagodnością i bojaźnią" (1 P 3, 16). Apostoł Paweł zaleca chrześcijanom: „Mowa wasza niech będzie zawsze uprzejma, zaprawiona solą, abyście wiedzieli, jak macie odpowiadać każdemu" (List św. Pawła Kolosan 4, 6). W związku z tym postawa triumfalizmu związana z brakiem szacunku dla Koranu jest jawnym przejawem braku wrażliwości i ignorancji, która bardziej dzieli niż buduje posłannictwo ewangelii wśród muzułmanów. Misjonarze przez wieki uważali Koran za księgę diabelską i wielokrotnie z zasady ją zupełnie odrzucali i jej nie studiowali. Jest wiele mitów o Mahomecie, islamie i Koranie, które zostały szeroko rozpowszechnione wśród chrześcijan i do dzisiaj przeszkadzają w budowaniu więzi z muzułmanami. Jednym z negatywnych skutków takiego myślenia może być kształtowanie ideologii i postawy wojny z islamem.

Z perspektywy rozwoju działań misyjnych w oparciu o zasady kontekstualizacji należy przełamywać stereotypy w myśleniu o islamie, by bezkrytycznie nie powielać uprzedzeń, które mogą nie mieć oparcia w faktach. John Gilchrist, wieloletni misjonarz wśród muzułmanów w Południowej Afryce, zaangażowany w dialog z takimi przywódcami muzułmańskimi, jak Ahmed Deedat, Adam Peerbhai czy Yusuf Buckas, pisze o tym, że w swojej pracy spotkał wielu chrześcijan, którzy mówią o swojej nienawiści do islamu z jednoczesnym podkreśleniem miłości w stosunku do muzułmanów ${ }^{15}$. To w jego ocenie jest postawa niedopuszczalna. Bardziej właściwą z misjologicznej perspektywy jest okazywanie miłości wszystkim muzułmanom i staranie się o to, by jak najlepiej zrozumieć kulturę islamu ${ }^{16}$. Im bardziej chrześcijanie są gotowi uczyć się na temat zasad kierujących życiem muzułmanów i poprzez to nabierać większego szacunku

\footnotetext{
${ }^{15}$ J. Gilchrist, Facing the Muslim Challenge, Cape Town 1999, s. 10.

16 Tamże, s. $12 \mathrm{nn}$.
} 
do ich wyznania wiary, tym bardziej otwiera to możliwości słuchania chrześcijan i budowania więzi. Niezwykle istotnym aspektem misji chrześcijańskiej jest więc to, aby kształtować właściwą postawę w oparciu o ustanowienie kulturowo wspólnej płaszczyzny z odbiorcami posłannictwa Ewangelii. Doświadczony w pracy z muzułmanami egipski misjonarz i teolog Fouad Elias Accad trafnie zauważa i podkreśla, że Koran może stanowić pomost do dzielenia się posłannictwem biblijnym. Nawiązując do przykładu apostoła Pawła, który zwrócił się do thumu zgromadzonego w Areopagu w Atenach (Dz 17), Accad zachęca do rozwoju podobnej postawy wobec muzułmanów. Apostoł Paweł, odwołując się do symboliki i wartości lokalnej kultury, dzieli się poselstwem o Chrystu$\mathrm{sie}^{17}$. Jest to przykładem przyjaznego podejścia do muzułmanów w oderwaniu od stereotypowych uprzedzeń. William C. Smith, wieloletni kierownik centrum studiów islamistycznych przy Uniwersytecie Harvarda, tak pisze na temat muzułmańskiego rozumienia Koranu: „Muzułmanie nie czytają Koranu i dochodzą do wniosku, że jest on od Boga; raczej wierzą w to, że jest od Boga i wtedy go czytają. To jest wielka różnica i zachęcam chrześcijan i świeckich studentów Koranu, jeśli chcą go zrozumieć jako dokument religijny, muszą do tego podejść w podobnym duchu..." ${ }^{18}$ Według tak postawionego argumentu, istnieje różnica pomiędzy tym, kiedy ktoś, nie będąc muzułmaninem, czyta Koran i zadaje sobie pytanie: „Co jest w tych słowach, że wyznawcy islamu uznają je za boskie objawienie?”, a poszukiwaniem odpowiedzi z innej perspektywy: „Co te słowa znaczyłyby dla mnie, jeśli wierzyłbym, że są one słowem Bożym?" ${ }^{19}$ Wielu chrześcijan nie wie o tym, że Koran zawiera liczne odniesienia do Biblii i symboliki biblijnej. W Koranie znajdujemy opisy wydarzeń od Adama do Ezdrasza, jak i opowieści o wielkich prorokach i wysłannikach Boga działających przed Muhammadem $^{20}$. Islam na podstawie nauczania Koranu utrzymuje też, że jest wiarą obejmującą wszystkich proroków, w tym Mojżesza i Jezusa. Wobec tego ważne jest, aby poznać wątki biblijne zawarte w Koranie, a w szczególności te w odniesieniu do Jezusa, gdyż one stanowią dla muzułmanów najważniejsze źródło wiedzy o Nim. Okazuje się bowiem, że znajduje się tam wiele cennych punktów odniesienia do Jezusa, które mogą stanowić dobry pomost do rozmowy.

Jezus, nazywany w Koranie Isa, pojawia się ponad trzydzieści razy zarówno w krótkich wzmiankach, jak i większych fragmentach narracyjnych ${ }^{21}$. Isa jest nazwany „sługą Boga” (abd Allah), ,posłańcem” (rasul), „Mesjaszem” (al-

\footnotetext{
${ }^{17}$ F. E. Accad, Building Bridges, Colorado Springs 1997.

${ }^{18}$ Cyt. za: G. W. Braswell, Islam. Its Prophet, Peoples, Politics and Power, Nashville 1996,

19 Tamże, s. 285.

${ }^{20}$ M. i U. Tworuschka, Islam. Mały Słownik, przekł. J. Marzęcki, Warszawa 1995, s. 17.

${ }^{21}$ U. Ryad, Koraniczne perspektywy dialogu międzyreligijnego, [w:] Księgi Święte płaszczyzna dialogu?, pod red. nauk. J. J. Stefanowa i A. Wąsa, Warszawa 2006, s. 97.
} s. 285. 
Masih), „Słowem Bożym” (kalima), „Duchem Bożym” (ruh) oraz zwiastunem Pisma Świętego, Ewangelii (indżil) ujmowanej jako Księga ${ }^{22}$. Muzułmanie dażą więc Jezusa wielkim szacunkiem i uznają go za jednego $\mathrm{z}$ wielkich proroków. Nie uważają jednak Jezusa za „Syna Bożego”, gdyż według teologii muzułmańskiej byłoby to bluźnierstwo. Koran po prostu nazywa Jezusa „synem Marii”. Islam także kategorycznie odrzuca dzieło zbawcze Jezusa, podobnie jak śmierć Jezusa na krzyżu, bowiem w świetle przekazu koranicznego „żaden człowiek nie może odpowiadać za winy drugiego człowieka, i żaden człowiek nie może dźwigać jego zła, tym bardziej, nikt nie może wyzwalać drugiego człowieka z jego własnej osobistej winy (zob. sura 6, 146; 45, 15)"'23. Pomimo tych zasadniczych różnic w biblijnym i koranicznym rozumieniu Jezusa, należy podkreślić, iż Isa jest postrzegany przez muzułmanów jako postać wyjątkowa. W opublikowanym w 2007 roku liście 138 uczonych i zwierzchników muzułmańskich do przywódców chrześcijańskich o znamiennym tytule Jednakowe stowo dla nas i dla was, tak oto napisano na temat muzułmańskiego pojmowania Jezusa: „Muzułmanie uznają Jezusa Chrystusa jako Mesjasza nie w taki sam sposób, jak chrześcijanie, [...] lecz następujący: Mesjasz Jezus, Syn Marii, jest tylko posłańcem Bożym, i Jego Słowem, które złożył Marii, i Duchem pochodzącym od Niego..." 24 . Islam i chrześcijaństwo ukazują więc dwa różne oblicza Jezusa. Koraniczny Isa nigdy nie był ukrzyżowany i nie jest uznawany za Zbawiciela świata, ale jednak według teologii islamu jest synem Marii, Mesjaszem i tajemnicą ${ }^{25}$. Dlatego znany islamski uczony Tarif Khaldi, pisząc o Jezusie w relacjach chrześcijańsko-muzułmańskich, mówi o tym, że ,jest On tym, który w łatwy, wręcz naturalny sposób wyrasta ponad te dwa środowiska religijne, $\mathrm{z}$ jednej strony te, w którym został zrodzony, z drugiej te, gdzie został adoptowany"26. Istnieją zasadnicze różnice w pojmowaniu Boga, objawienia i zasad wiary prezentowanych przez chrześcijaństwo i islam. Z perspektywy misjologii ekumenicznej ważnym wyzwaniem staje się jednak wejście w dialog na poziomie życia, ze szczególnym podkreśleniem miłości Boga i miłości bliźniego. Taka postawa wymaga zachowania pewnej pokory teologicznej w relacjach z wyznawcami innych religii. Nie chodzi bynajmniej

${ }^{22}$ M. i U. Tworuschka, Islam..., s. 43.

${ }^{23}$ E. Sakowicz, Gtoszenie Chrystusa a dialog o Bogu z muzutmanami, [w:] Odkupienie a dialog międzyreligijny. Materiały z sympozjum w Obrze 20-21 kwietnia 1998 r., red. W. Kluj, Poznań 1999, s. 85.

${ }^{24}$ Cyt. za: J. Kubacki, Czy chrześcijanie potrzebuja innych religii?, „Życie Duchowe” 56 (2008), s. 18; por. E. Sakowicz, Głoszenie Chrystusa..., s. 84: „Jezus, jak twierdzi tradycja islamu, nie przyszedł na świat, aby dokonać dzieła odkupienia, ale by wezwać wszystkich ludzi, by na powrót stali się sługami Allaha, poddanymi jego woli”.

${ }^{25}$ Zob. G. Parrinder, Jesus in the Qur'an, New York 1977.

${ }^{26}$ Cyt. za: D. W. Shenk, Faithful Christian Witness Among Muslims, [w:] Christian Presence and Witness Among Muslims, ed. P. Penner, Schwarzenfeld 2005, s. 34. 
o rozmywanie prawdy, podważanie własnej tożsamości religijnej czy rezygnację z własnych przekonań uznawanych za prawdziwe. Ważnym jest zachowanie właściwego balansu pomiędzy wyznawanymi prawdami wiary a życiem wiary. W tym ujęciu misji chrześcijańskiej istotnym jest ogłaszanie ewangelii, ale w sposób, który wskazuje na jej aktualność w życiu odbiorcy. Z chrześcijańskiej perspektywy wydaje się to być nieosiągalne bez ofiarowania samego siebie, bez swego rodzaju kenozy i oddania na wzór Chrystusa. Taka postawa wymaga głębokiego poczucia pokory, która otwiera możliwość stworzenia przestrzeni na to, aby nie tylko dawać, ale także otrzymywać od 'innego'.

Należy więc podkreślić relacyjny i dialogiczny charakter chrześcijańskiej misji wśród muzułmanów. Biorąc pod uwagę to, co już zostało powiedziane na temat kształtowania postawy dialogu i otwartości na 'inność', budowanie relacji z drugim człowiekiem staje się fundamentem wiarygodności głoszonego posłannictwa. Innymi słowy, najpełniejsze przedstawienie ewangelii ma miejsce wtedy, kiedy wartości Chrystusowe wyrażane są w naszych relacjach z innymi ludźmi. W tym sensie kontakt z drugą osobą nie zakłada jedynie jednostronnej przemiany. W praktyce oznacza to rozwój większej wrażliwości wobec 'innego', dowartościowanie roli słuchania w procesie ewangelizacyjnym, a także podkreślenie roli twórczego dialogu. W dialogu tym nie chodzi tylko o stricte filozoficzny wymiar wymiany poglądów. Bardziej istotne jest wejście w interakcję na poziomie życia codziennego w oparciu o wzajemny szacunek. Taki dialog ubogaca i otwiera szersze perspektywy, które pomagają w przełamaniu głęboko zakorzenionych uprzedzeń wobec 'innego' wynikających z różnych doświadczeń w historii oraz różnic teologicznych. Są miejsca w Koranie, które ostrzegają muzułmanów przed zawieraniem przyjaźni z chrześcijanami (por. sura 5, 51) i obwiniają ich o bałwochwalstwo przez uznanie Isa za Syna Bożego, atakują ich za uwielbianie trzech bóstw (por. sura 5, 75-76) ${ }^{27}$. Jednocześnie możemy znaleźć koraniczne wypowiedzi chwalące ludzi księgi za ich sprawiedliwość, dobre czyny oraz za wiarę w życie pośmiertne (por. sura 3, 113) ${ }^{28}$. Nie chodzi więc bynajmniej o zrelatywizowanie pojęcia prawdy, lecz utrzymanie ciągłego dyskursu i otwartości na ustanowienie relacji dialogicznego współistnienia z innymi. Taka postawa dialogu jest dla jego uczestników zarówno szansą na wzajemne poznanie i wzbogacenie jak i wyzwaniem do głębszej refleksji nad podstawami swojej wiary. W efekcie takiego podejścia, jak czytamy w deklaracji międzynarodowej konferencji teologicznej o ewangelizacji i dialogu: „,następuje wzajemne wzbogacenie duchowe, które może być wynikiem tej braterskiej wymiany doświadczeń religijnych. Wzbogacenie to wypływa z faktu, iż w dialogu każdy partner słucha Boga, odsłaniając samego siebie i zadając

\footnotetext{
${ }^{27}$ U. Ryad, Koraniczne..., s. 103.

${ }^{28}$ Tamże, s. 97-98.
} 
pytania swym wierzącym braciom. Prowadzi to do rozwoju duchowego i, co za tym idzie, do pewnego rodzaju głębszej matanoi, nawrócenia się do Boga"29. Jak to ujął David Shenk, menonicki teolog od wielu lat zaangażowany w dialog chrześcijańsko-muzułmański: „Odkryliśmy, że rozmowy pomiędzy różnymi wspólnotami religijnymi i ideologicznymi mogą wzniecać ducha wzajemnej współpracy dla dobra ludzi i ludzkości”30.

Kontekstualizacja wydaje się więc niezwykle ważnym narzędziem we współczesnej refleksji misjologicznej. W praktyce misji w krajach muzułmańskich funkcjonuje duża różnorodność modeli, mniej lub bardziej związanych z zachodnimi formami chrześcijaństwa. Ciekawej próby ukazania tego spektrum podjął się John Travis, który na podstawie przeprowadzonych badań podzielił je na sześć modeli ${ }^{11}$. Jego wnioski można podsumować w następujący sposób:

\begin{tabular}{|l|l|l|l|l|l|l|}
\hline & \multicolumn{1}{|c|}{ C1 } & \multicolumn{1}{c|}{ C2 } & \multicolumn{1}{c|}{ C3 } & \multicolumn{1}{c|}{ C4 } & \multicolumn{1}{c|}{ C5 } & \multicolumn{1}{c|}{ C6 } \\
\hline $\begin{array}{l}\text { Obraz } \\
\text { Kościoła }\end{array}$ & $\begin{array}{l}\text { Tradycyjny } \\
\text { Kościół } \\
\text { w oddzieleniu } \\
\text { od kultury } \\
\text { muzułmań- } \\
\text { skiej }\end{array}$ & $\begin{array}{l}\text { C1 } \\
\text { w formie, ale } \\
\text { używajacy } \\
\text { języka naro- } \\
\text { dowego }\end{array}$ & $\begin{array}{l}\text { C2 wyko- } \\
\text { rzystujący } \\
\text { elementy } \\
\text { kultury muzuł- } \\
\text { mańskiej (np. } \\
\text { ubiór, muzyka) }\end{array}$ & $\begin{array}{l}\text { C3 stosujący } \\
\text { biblijnie } \\
\text { uzasadnio- } \\
\text { ne praktyki } \\
\text { islamu }\end{array}$ & $\begin{array}{l}\text { C4 } \\
\text { uznajacy się } \\
\text { za „muzuł- } \\
\text { mańskiego } \\
\text { naśladowcę } \\
\text { Jezusa” }\end{array}$ & $\begin{array}{l}\text { Ukryci wierza- } \\
\text { cy, aktywnie } \\
\text { zaangażowani } \\
\text { (lub nie) w ży- } \\
\text { cie religijne } \\
\text { islamu }\end{array}$ \\
\hline $\begin{array}{l}\text { Obraz } \\
\text { siebie }\end{array}$ & Chrześcijanin & Chrześcijanin & Chrześcijanin & $\begin{array}{l}\text { Naśladowca } \\
\text { Isa }\end{array}$ & $\begin{array}{l}\text { Muzułmański } \\
\text { naśladowca } \\
\text { Jezusa } \\
\text { chrześcijanin, } \\
\text { lub naśladow- } \\
\text { ca Isa, lub } \\
\text { muzułmański } \\
\text { naśladowca } \\
\text { Isa }\end{array}$ \\
\hline $\begin{array}{l}\text { Percepcja } \\
\text { muzułmańska }\end{array}$ & Chrześcijanin & Chrześcijanin & Chrześcijanin & $\begin{array}{l}\text { 'Inny' } \\
\text { chrześcijanin }\end{array}$ & $\begin{array}{l}\text { 'Dziwny' } \\
\text { muzułmanin }\end{array}$ & Muzułmanin \\
\hline
\end{tabular}

Według tej typologii C1 i C2 nie wykazują się wielkim zainteresowaniem dostosowaniem swojej formy do kultury muzułmańskiej (poza stosowaniem języka tej kultury w przypadku C2). Tego rodzaju podejście skazuje kościoły na marginalizację społeczno-religijną w kulturze muzułmańskiej i w dużym stopniu pozostaje pod wpływem tradycyjnych form ewangelizacji w stylu zachodnim. Model C3 wykazuje się większą inicjatywą akomodacji i dostosowania się do lokalnej kultury, ale dotyczy to tylko sfery pozareligijnej, a więc na przykład form ubioru, diety, muzyki czy sztuki. Lokalne rytuały czy tradycje, aby w ogóle można je było wykorzystać, muszą być według modelu C3 najpierw przefiltrowane w świetle Biblii. Jest tutaj wyraźne rozdzielenie pomiędzy praktykami, które są uznawane

${ }^{29}$ Cyt. za: M. Patalon, Dialogiczny charakter misji chrześcijańskiej, [w:] Misja w Polsce jako problem międzykościelny, pod red. T. J. Zielińskiego, Warszawa-Katowice 2006, s. 50.

${ }^{30}$ D. W. Shenk, Global Gods. Exploring the Role of Religions in Modern Societies, Scottdale 1999, s. 381.

${ }^{31}$ J. Travis, The C1 to C6 Spectrum, „Evangelical Missions Quarterly” 34 (1998) nr 4, s.407-408. 
za „,czysto kulturowe”, a muzułmańskimi, na jakie w tym modelu nie można sobie pozwolić ${ }^{32}$. Ten model pozostaje bliski wielu misjonarzom zachodnim ze względu na kontrast, $\mathrm{w}$ jakim stawia chrześcijaństwo i islam, z jednoczesną otwartością na niektóre zewnętrzne formy akomodacji kulturowej. Model C6 stanowi z kolei bardziej strategię przetrwania niż formę kontekstualizacji i jako taki oscyluje w postawie między zachowaniem całkowitej anonimowości w sprawach wiary, a byciem prześladowanym za swoje przekonania.

Najwięcej kontrowersji wśród protestanckich misjonarzy wzbudza kontekstualizacja w modelach C4 i C5. Tutaj następuje rozróżnienie na poziomie postrzegania swojej tożsamości. Odcinając się od negatywnego bagażu kojarzonego z różnymi formami oddzielania się chrześcijaństwa od kultury muzułmańskiej, ludzie wierzący w kategorii C4 nie nazywają siebie „chrześcijanami”, ale częściej stosują określenie „naśladowca Isa”. Nie obawiają się oni praktykować różnych muzułmańskich form religijności, które jednak według nich nie zaprzeczają wartościom biblijnym (np. postawa w czasie modlitwy, abstynencja od alkoholu i niektórych potraw, stosowanie wybranej muzułmańskiej terminologii religijnej, itp.). Taka forma kontekstualizacji pozwala na praktykowanie prawd chrześcijaństwa w formach, które są bardziej czytelne i zrozumiałe w muzułmańskich kręgach kulturowych. Chociaż istnieje wiele znaczących rozbieżności pomiędzy islamem a chrześcijaństwem, są też elementy, które mogą łączyć obie religie i stanowić inspirację do głębszego oddania się Bogu. Gerald R. McDermott, po ukazaniu różnic, jakie oddzielają te dwie religie w pojmowaniu Boga, źródła objawienia i pism uznawanych za święte, wskazuje na pewne lekcje, które można wynieść z praktyk muzułmańskich poddania się Bogu, regularnych teocentrycznych modlitw czy troski o ubogich ${ }^{33}$. W modelu C4 naśladowcy Isa dążą do tego, aby jak najszerzej korzystać z bogactwa form religijności islamu, jednak z wyraźnym akcentem położonym na wyznanie wiary w Jezusa. Stąd wierzący praktykujący model kontekstualizacji C4 są nadal postrzegani jako chrześcijanie, chociaż stosują pewne zaadaptowane $\mathrm{z}$ islamu zewnętrzne formy religijności, to nie biorą oni udziału w rytualnym życiu w meczecie. Model C5 jest bardzo podobny do C4, ale główna różnica leży w samookreśleniu własnej tożsamości nie jako „naśladowcy Isa”, ale jako „muzułmańskiego naśladowcy Isa”. To rozróżnienie jest o tyle ważne, że wierzący praktykujący model C5 są nadal uznawani przez muzułmanów jako część ich grupy religijnej. Mogą oni podlegać pewnym restrykcjom, ale generalnie uczęszczają do meczetu, odmawiają tradycyjne muzułmańskie modlitwy, poszczą i swoim stylem życia nie odróżniają się zbytnio

${ }^{32}$ J. Massey, God's Amazing Diversity in Drawing Muslims to Christ, „International Journal of Frontier Missions" 17 (2000) nr 1, s. 7.

${ }^{33}$ G. R. McDermott, Can Evangelicals Learn from World Religions? Jesus Revelation and Religious Traditions, Downers Grove 2000, s. 194-205. 
od swych sąsiadów. Ich odrębność polega na tym, że reinterpretują koraniczne nauczanie w świetle Biblii, a część doktryn muzułmańskich odrzucają. Poza tym spotykają się regularnie poza meczetem, aby wspólnie studiować Biblię, modlić się o siebie i kształtować w wierze chrześcijańskiej3 ${ }^{34}$ Tego rodzaju postawa kontekstualizacji jest już dla wielu misjonarzy pójściem o krok za daleko w kierunku synkretyzmu, który pociąga za sobą niebezpieczeństwo zatracenia własnej tożsamości i odrębności chrześcijańskiej ${ }^{35}$. Istotą problemu jest to, na ile wierzący zaliczający się do grona C5 zachowują integralność nauczania i posłannictwa Chrystusa w obliczu praktykowania różnych muzułmańskich rytuałów religijnych i dlatego czasami bywają porównywani do judaizujących chrześcijan w Nowym Testamencie lub Żydów mesjanistycznych ${ }^{36}$. Ta różnorodność modeli kontekstualizacji wskazuje na szerokie zaangażowanie oraz zmiany, które następują w praktyce misji wśród muzułmanów.

\section{Praska Deklaracja dotycząca chrześcijańskiej obecności i służby wśród muzułmanów w oparciu o miłość}

W konkluzji chciałbym przytoczyć fragmenty opracowanej przez protestantów Praskiej Deklaracji dotyczącej chrześcijańskiej obecności i służby wśród muzułmanów w oparciu o miłośśc ${ }^{37}$.

Z preambuły dowiadujemy się, że dokument ten został sformułowany podczas konferencji misyjnej odbywającej się w Międzynarodowym Baptystycznym Seminarium Teologicznym w Pradze w 2004 roku, na której reprezentowani byli przedstawiciele 31 krajów z Europy, Azji, Bliskiego Wschodu, Afryki, Ameryki Północnej i Południowej. Główną ideą tego spotkania było to „aby uczyć się od siebie nawzajem jak najlepiej rozwijać postawę dialogu i autentycznej chrześcijańskiej obecności w różnych kontekstach w relacji z muzułmanami." ${ }^{38}$

Następnie dokument ten opisuje różne konteksty, w których chrześcijańskie kościoły stanowią mniejszość i bywają marginalizowane, a także muszą żyć z konsekwencjami historycznie ukształtowanych uprzedzeń wobec muzułmanów

${ }^{34}$ J. Massey, God's Amazing..., s. 8-14.

${ }^{35}$ P. Parshall, Danger! New Directions in Contextualization, „Evangelical Missions Quarterly” 34 (1998) nr 4, s. 404-406; 409-410; por. The unique Christ in our pluralist world, ed. by B. J. Nicholls, Carlisle 1994, s. 31-78.

${ }^{36}$ R. Jameson, N. Scalevich, First-Century Jews and Twentieth-Century Muslims, „The International Journal of Frontier Missions" 17 (2000) nr 1, s. 33-40; por. J. Travis, A. Workman, Messianic Muslim Followers of Isa: A Closer Look at C5 Believers and Congregations, "The International Journal of Frontier Missions" 17 (2000) nr 1, s. 53-60.

${ }^{37}$ The Prague Declaration on Christian Presence and Loving Service amongst Muslims, [w:] Christian Presence..., s. 15-19.

${ }^{38}$ Tamże, s. 15. 
jak i na odwrót. Jednocześnie znajdujemy tutaj ostrzeżenie przed promowaniem negatywnych postaw, które nie wyrażają ducha Ewangelii.

W sekcji dokumentu nazwanej „Our identity” (Nasza tożsamość) znajdujemy wyraźne wyznanie wiary dotyczące stwórczego dzieła Boga (paragraf 1), powołania do braterstwa w oparciu o miłość (paragraf 2) i przebaczenia Bożego poprzez zbawcze dzieło Chrystusa oraz powołanie do życia w budowaniu wspólnoty z innymi w mocy Ducha Świętego (paragraf 3) ${ }^{39}$. Deklaracja ta wyraźnie zaznacza w tym punkcie, że naturalną konsekwencją więzi z Bogiem jest okazywanie miłości muzułmanom bez względu na ich narodowość.

W odpowiedzi na obecne wyzwania deklaracja zachęca chrześcijan między innymi do:

- budowania więzi z muzułmanami w oparciu o przyjaźń i zaufanie,

- budowania pomostów pokoju, z uznaniem, że jedynie miłość i przebaczenie są odpowiedzią na przełamanie wzajemnych barier, oskarżeń, aktów przemocy i chęci rewanżu,

- działania na rzecz sprawiedliwości i pojednania w oparciu o uznanie godności nadanej każdemu człowiekowi przez Boga,

- praktykowania i propagowania postawy miłosierdzia, zapraszając wszystkich do udziału w Bożym błogosławieństwie

- budowanie bliskiej więzi z Jezusem i kształtowania wspólnot otwartych i głęboko osadzonych w lokalnym kontekście kulturowym ${ }^{40}$.

Według Praskiej Deklaracji chrześcijanie są więc powołani do obecności i świadectwa wśród muzułmanów w oparciu o kultywowanie postawy miłości i wzajemnego szacunku, które mają być odzwierciedleniem ducha Chrystusowego.

\section{Summary}

\section{Protestantism and Islam from the missiological perspective}

The presence of Christian missionaries amongst Muslims has raised numerous controversies from the very beginnings of the missionary movement. The history of missions shows that the missionary idea was far too frequently identified with colonialism as the missionary concept was regarded as superior to other cultures views.

Such an attitude towards missions often led to the objectification of other cultures and religions as territories to be conquered and, consequently, increasing conflicts and divisions. It also had a great impact upon shaping a particular picture of the relations between Christian missionaries and Muslims.

In order to build bridges between Christianity and Islam in the light of the new ecumenical paradigm of missions one needs first to realize and revise improper attitudes and assumptions made by Christian missionaries. It may be assumed that at first missionaries entered the Muslim culture with the vision of Western-style Christanisation, without paying proper respect to the religious values deeply rooted in the given culture. Such an attitude favored the development

\footnotetext{
${ }^{39}$ Tamże, s. 17.

${ }^{40}$ Tamże, s. 18.
} 
of mutual prejudice or even conflict. The crusade mentality which was represented by numerous Christian missionaries had been an attempt to gain new converts from among Muslims, often resulting in antagonistic attitudes from Islamic followers towards Christians. In time, however, such attitudes changed for the benefit of searching for Christian elements in Muslim culture. Hence the reading of the Koran with considering Christian elements (e.g. the Koranic term of Isa - Jesus, al-Masih - Messiah, and others) and an attempt to build bridges on their foundations. The missiological trend with the largest number of possibilities currently being contextualised, although it functions in various models (it has been presented in detail by, among others, John Travis).

Translated by Joanna Malak 